\title{
Synthesis and Screening of Biologically active Schiff bases of Benzothiazoles and its Zinc and Lanthanum metal complexes
}

\author{
D. G. ANUSE ${ }^{1 \star}$, V. J. DESALE', B. R. THORAT ${ }^{1}$, D. D. ANUSE ${ }^{2}$, S. G. JAGADHANI2, \\ K. GEORGE ABRAHAM ${ }^{3}$ and R. S.YAMAGAR ${ }^{4 *}$ \\ 'Department of Chemistry, Government of Maharashtra's Ismail Yusuf \\ College of Arts Science and Commerce, Mumbai 400060, India. \\ ${ }^{2}$ Veer Wajekar A. S. C. College, Phunde, Tal. Uran, Dist. Raigad, India. \\ ${ }^{3}$ SIES College of Arts, Science and Commerce, Sion (West), Mumbai 400022, India. \\ ${ }^{4}$ Chikitsak Samuha's Patkar-Varde College of Arts, Science and Commerce, \\ Goregaon (west), Mumbai 400 062, India. \\ ${ }^{*}$ Corresponding author E-mail: devidasanuse@ gmail.com
}

http://dx.doi.org/10.13005/ojc/370126

(Received: December 23, 2020; Accepted: February 18, 2021)

\section{ABSTRACT}

The substituted 2-Aminobenzothiazole and ethyl 2-(4-formyl-3-hydroxyphenyl)-4methylthiazole-5-carboxylate in methanol mix together and heat the reaction mixture for overnight, It gives Schiff's bases (derivatives of substituted aminobenzothiazole) 3.This compound $\mathbf{3}$ when treated with zinc chloride it gives zinc metal complex of Schiff's bases $\mathbf{4}$ and if compound $\mathbf{3}$ was treated with Lanthanum chloride gives Lanthanum metal complex of Schiff's bases $\mathbf{5}$, which shows marked biological activities.

Keywords: 2-Aminobenzothiazole, Zinc chloride, Lanthanum chloride, Metal complex.

INTRODUCTION

The benzothiazole derivatives show wide range of biological activities which include analgesic ${ }^{1}$, anti-inflammatory ${ }^{2}$, antiviral ${ }^{3}$, antibacterial ${ }^{4}$ and anticancer activities.

Preparation and screening of 2-Aminobenzothiazole derivatives in vitro as potential antimicrobial activity, which shows remarkable antifungal activity $^{5}$. Hugo Schiff reported the condensation of primary amines with carbonyl compounds known as Schiff's bases which reported in $1864^{6}$. Nowadays, Schiff base coordination chemistry has expanded enormously in the field of research. Advantages of Schiff base complexes for biological applications, bioinorganic chemistry, material science, supramolecular chemistry, catalysis and separation and summarize processes, and formation of compounds with unusual properties and structures has been well recognized and reviewed. ${ }^{7}$

Schiff Bases are characterized by the Imine $(-\mathrm{N}=\mathrm{CH}-)$ group which carries out the mechanism

This is an Open Access article licensed under a Creative Commons license: Attribution 4.0 International (CC- BY). Published by Oriental Scientific Publishing Company @ 2018

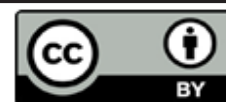


of transamination and racemization reaction in biological system ${ }^{8,9}$

Several Schiff's bases are listed to get outstanding antibacterial, antifungal and anticancer activities ${ }^{10,11,12,13}$.

Lanthanide complexes showed importance in cancer diagnosis and therapy. Lanthanide-based tiny molecules as well as nonmaterial's have been scrutinize as cytotoxic agents and constraint, in photodynamic treatment, radiation therapy, drug delivery. ${ }^{14}$

The Zn (II) complex has a very interesting and varied pharmacological activity. Zn (II) complex are effective against gastric mucosal injuries ${ }^{15,16,17}$ shows a potent anti-ulcer activity and is also effective against Helicobacter pylori, a causative agent for stomach ulcers.

\section{Present work}

\section{Experimental Procedure for Schiff's bases}

The equimolar solutions of 2-aminoben- zothiazole and ethyl 2-(4-formyl-3-hydroxyphenyl)4-methylthiazole-5-carboxylate were stirred in $10 \mathrm{~mL}$ of methanol. The reaction mixture was then heated overnight for 12 to 14 hours. The completion of reaction was monitored by thin layer chromatography (TLC) using hexane: Ethyl Acetate (8:2). The reaction mixture was gradually cool at room temperature. The reaction mixture was then filtered and washed with $5 \mathrm{~mL}$ of methanol. The wet sample was dried at $50^{\circ} \mathrm{C}$ in oven for 5 hours. The product obtained was yellow dry solid with the yield of $95 \%$.

\section{EXPERIMENTAL}

Infrared spectra were recorded in $\mathrm{KBr}$ disc on Shimadzu FTIR Spectrophotometer. ${ }^{1} \mathrm{H}$ NMR spectra were recorded on a Bruker Avance II 400 $\mathrm{MHz}$ spectrophotometer DMSO- $\mathrm{d}_{6}$ as a solvent and TMS as an internal standard (chemical shift in $\delta$ values). Mass spectra were analyzed in Finnigan mass spectrometer. Purity of the compounds was checked by TLC on silica gel plates.<smiles>[R][X]C=Cc1cc(-c2nc(C)c(C(=O)OCC)s2)ccc1O</smiles><smiles>[R10]CC(C)C(OC)OC(C)=O</smiles>

Scheme. 1

Table 1: Spectral Data of synthesized Schiff's Bases

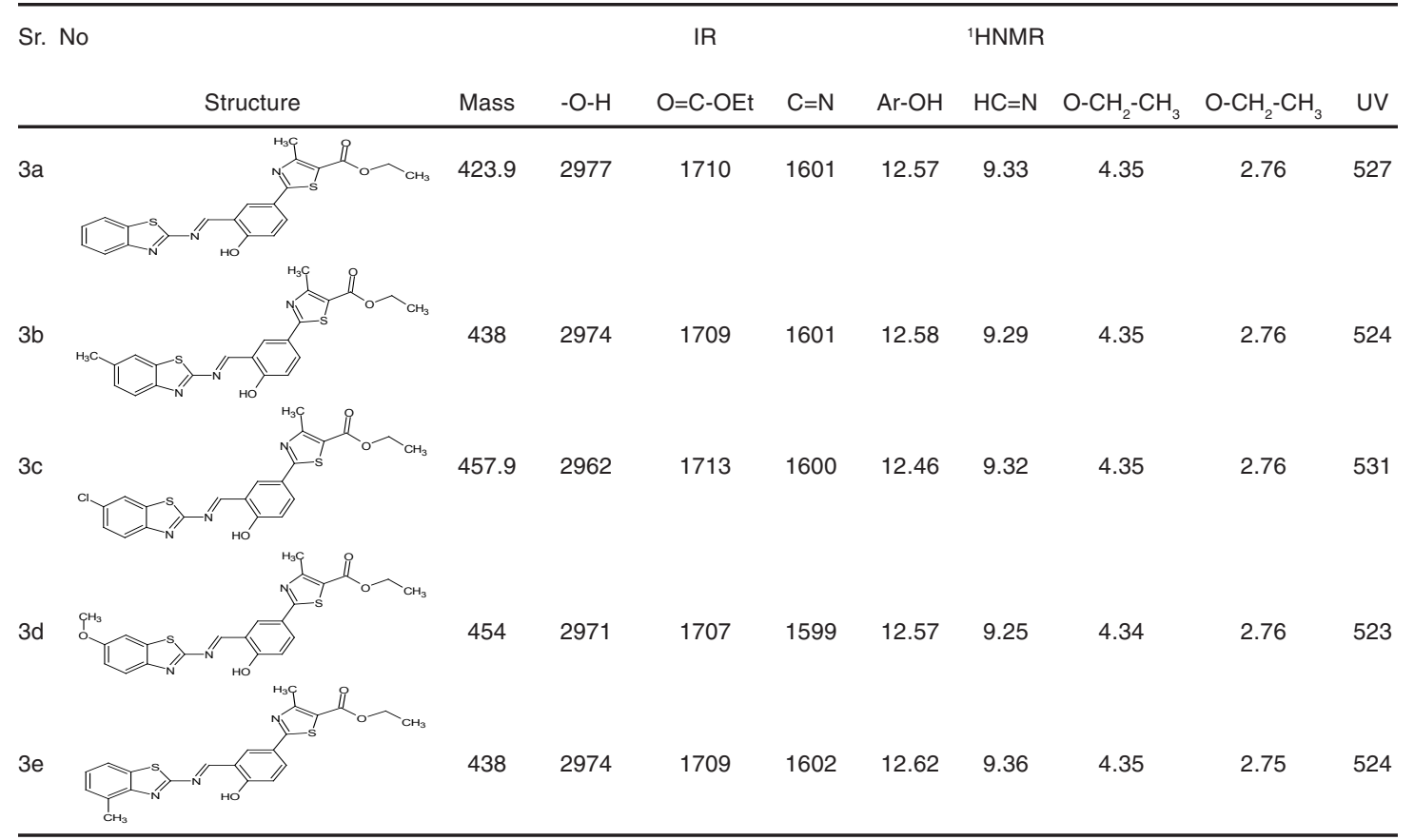



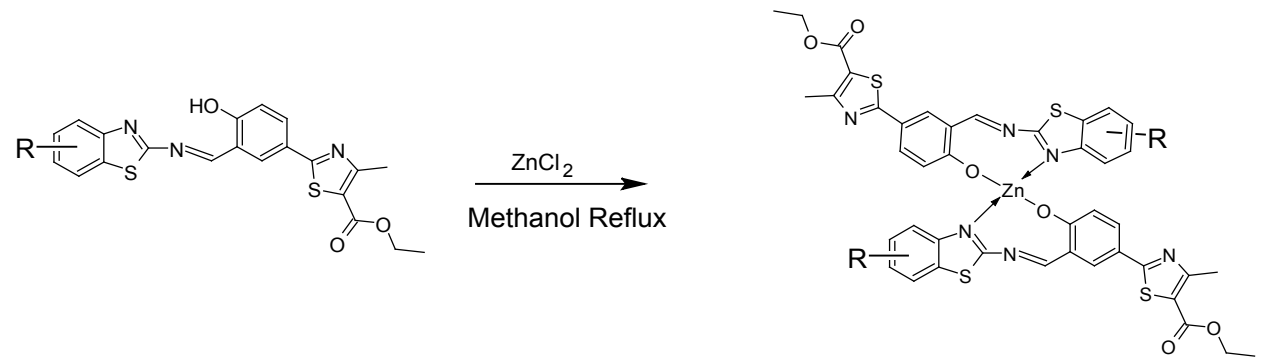

Scheme. 2

Experimental procedure for zinc metal complexes Synthesis of Bis[ethyl2-(4-hydroxy-3-\{(E)-[(1,3benzothiazol-2-yl)inimo]methyl\} phenyl)-4methyl-1,3-thiazole-5-carboxy- late]zinc(II)

The solution of ligand $3 a-3 e(2.36 \mathrm{mmol})$ was stirred in $30 \mathrm{~mL}$ methanol. Zinc chloride ${ }^{18}$ solution $(1.18 \mathrm{mmol}$ in $10 \mathrm{~mL}$ methanol) was added dropwise in reaction mixture. The $\mathrm{pH}$ of 5.6 was adjusted by using sodium carbonate. The reaction mixture was then

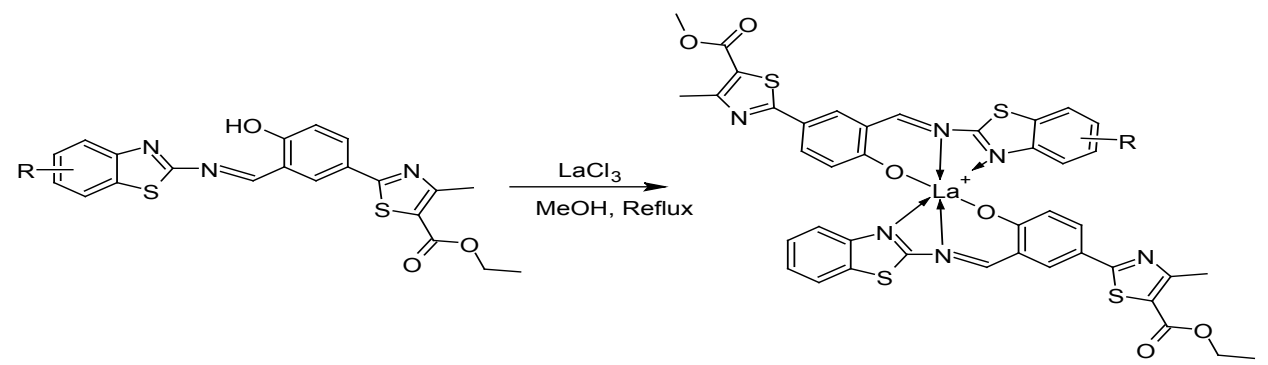

Scheme. 3

Table 2: Biological Activities of Synthesized Schiff's Bases (Ligands)

\begin{tabular}{|c|c|c|c|c|c|c|c|c|}
\hline \multirow[t]{2}{*}{ Sr.No. } & \multirow[t]{2}{*}{ Microorganism } & \multicolumn{5}{|c|}{ MIC value for Schiff's bases of benzothiazole in $\mu \mathrm{g} / \mathrm{mL}$} & \multirow[t]{2}{*}{ Ciprofloxacin } & \multirow[t]{2}{*}{ Fluconazole } \\
\hline & & $3 a$ & $3 b$ & $3 c$ & $3 d$ & $3 e$ & & \\
\hline 1 & C. albicans & 25 & 12.5 & 12.5 & 12.5 & 25 & - & 10 \\
\hline 2 & E.coli & 12.5 & 12.5 & 12.5 & 12.5 & 25 & 2 & - \\
\hline 3 & Staphylococcus aureus & 12.5 & 12.5 & 12.5 & 6.25 & 25 & 2 & - \\
\hline 4 & Klebsiella pneumoniae & 12.5 & 12.5 & 12.5 & 12.5 & 25 & 1 & - \\
\hline 5 & Bacillus subtilis & 12.5 & 12.5 & 12.5 & 6.25 & 25 & 2 & - \\
\hline 6 & Staphylococcus aureus & 12.5 & 12.5 & 12.5 & 12.5 & 25 & 2 & - \\
\hline
\end{tabular}

Table 3: Biological Activities of Synthesized Zinc Metal Complexes:

\begin{tabular}{|c|c|c|c|c|c|c|c|c|}
\hline \multirow[t]{2}{*}{ Sr.No. } & \multirow[t]{2}{*}{ Microorganism } & \multicolumn{5}{|c|}{ MIC value for Zinc $\mathrm{m} / \mathrm{c}$ in $\mu \mathrm{g} / \mathrm{mL}$} & \multirow[t]{2}{*}{ Ciprofloxacin } & \multirow[t]{2}{*}{ Fluconazole } \\
\hline & & $4 a$ & $4 b$ & $4 c$ & $4 d$ & $4 e$ & & \\
\hline 1 & C. albicans & 12.5 & 12.5 & 6.25 & 25 & 6.25 & - & 10 \\
\hline 2 & E.coli & 25 & 12.5 & 12.5 & 25 & 12.5 & 2 & - \\
\hline 3 & Staphylococcus aureus & 25 & 25 & 6.25 & 25 & 12.5 & 2 & - \\
\hline 4 & Klebsiella pneumoniae & 25 & 12.5 & 12.5 & 25 & 12.5 & 1 & - \\
\hline 5 & Bacillus subtilis & 25 & 25 & 6.25 & 25 & 12.5 & 2 & - \\
\hline 6 & Staphylococcus aureus & 25 & 25 & 25 & 25 & 12.5 & 2 & - \\
\hline
\end{tabular}


Table 4: Biological Activities of Synthesized Lanthanum Metal Complexes

\begin{tabular}{|c|c|c|c|c|c|c|c|c|}
\hline \multirow[t]{2}{*}{ Sr.No. } & \multirow[t]{2}{*}{ Microorganism } & \multicolumn{4}{|c|}{ MIC value for Lanthanum $\mathrm{M} / \mathrm{C}$ in $\mu \mathrm{g} / \mathrm{mL}$} & \multirow[b]{2}{*}{$5 e$} & \multirow[t]{2}{*}{ Ciprofloxacin } & \multirow[t]{2}{*}{ Fluconazole } \\
\hline & & $5 a$ & $5 b$ & $5 c$ & $5 d$ & & & \\
\hline 1 & C. albicans & 12.5 & 6.25 & 6.25 & 6.25 & 12.5 & - & 10 \\
\hline 2 & E.coli & 12.5 & 6.25 & 6.25 & 6.25 & 6.25 & 2 & - \\
\hline 3 & Staphylococcus aureus & 6.25 & 6.25 & 6.25 & 6.25 & 6.25 & 2 & - \\
\hline 4 & Klebsiella pneumoniae & 12.5 & 6.25 & 6.25 & 6.25 & 6.25 & 1 & - \\
\hline 5 & Bacillus subtilis & 6.25 & 12.5 & 6.25 & 6.25 & 6.25 & 2 & - \\
\hline 6 & Staphylococcus aureus & 6.25 & 12.5 & 6.25 & 6.25 & 6.25 & 2 & - \\
\hline
\end{tabular}

Experimental procedure for lanthanum metal complexes

Synthesis of Bis[ethyl2-(4-hydroxy-3-\{(E)-[(1,3benzothiazol-2-yl)inimo]methyl\} phenyl)-4methyl-1,3-thiazole-5-carbo -xylate]lanthanum(II) chloride

The equimolar amount of ligand $3 a$ to $3 e$ \& Lanthanum chloride $(1.18 \mathrm{mmol}$ in $10 \mathrm{~mL}$ of methanol) were mixed in $30 \mathrm{ml}$ methanol. It was added drop wise in reaction mixture and $\mathrm{pH} 5.6$ was maintained by using sodium carbonate. Then heat mixture was to $65-70^{\circ} \mathrm{C}$ for overnight 10 to 12 hours. The reaction mixtures gradually cool to ambient temperature. The volume of reaction was reduced to $10 \mathrm{~mL}$ under vacuum. Then $5 \mathrm{~mL}$ water was added drop wise to the reaction mixture with stirring for 30 minute. The reaction mixture filtered under vacuum. The wet solid was recrystallized using water and Methanol (7:3) at $60-65^{\circ} \mathrm{C}$ and the orange crystalline product $(5 \mathrm{a})$ was dried for 12 hours.

\section{Biological activity Antibacterial assay}

Antimicrobial of ligands and its metal complexes screened against three gram positive Staphylococcus aureus 1, Staphylococcus aureus 2 and Bacillus subtilis. Two Gram-negative like Klebsiella pneumonia and Escherichia coli and fungi Candida albicans to asset their potency as antimicrobial agent by minimum inhibition concentration (MIC) using microbiological method ${ }^{19}$. The test inoculums Staphylococcus aureus 1 ATCC 6538, Staphylococcus aureus 2 ATCC 33591, Bacillus subtilis ATCC 6051, Klebsiella pneumonia ATCC 4352, E coli ATCC 8739 and Candida albicans ATCC 24433. All ligands and its metal complexes have to be done with brain heart infusion (BHI) for Minimum inhibition concentration (MIC). Ingredients in brain heart Infusion $500 \mathrm{~g} /$ Liter contain Calf brain infusion form $200 \mathrm{~g}$, beef heart infusion form 200 $\mathrm{g}$, protease peptone $10 \mathrm{~g}$ dextrose $2 \mathrm{~g}$ sodium chloride $5 \mathrm{~g}$ disodium phosphate $2.5 \mathrm{~g}$. Fluconazole and ciprofloxacin are used as standard. Micro broth dilution method was used for standard drugs. For facultative anaerobes, tubes were incubated at $37^{\circ} \mathrm{C}$ for 48-72 $\mathrm{h}$ in carbon dioxide jar.

\section{In vitro Antimicrobial Study}

The study of MIC values of Ligand and its metal complexes indicated that complexes are exhibit the highest antimicrobial activity than the ligand, these results are shown in table number 2 , 3 and 4. C. albicans, (5a) lanthanum Complex good Antimicrobial activity $(12.5 \mu \mathrm{g} / \mathrm{mL})$ up to MIC value and (4a) zinc complex (12.5 $\mu \mathrm{g} / \mathrm{mL}$ ) compared to (3a) Ligand $(25 \mu \mathrm{g} / \mathrm{mL})$. (5b) lanthanum Complex good Antimicrobial activity $(6.25 \mu \mathrm{g} / \mathrm{mL})$ up to MIC value compared to (3b) Ligand (12.5 $\mathrm{gg} / \mathrm{mL})$ as well as (4b) zinc complex (12.5 $\mu \mathrm{g} / \mathrm{mL})$. (5c) lanthanum Complex good Antimicrobial activity $(6.25 \mu \mathrm{g} / \mathrm{mL})$ and $(4 \mathrm{c})$ zinc complex $(6.25 \mu \mathrm{g} / \mathrm{mL})$ up to MIC value compared to (3c) Ligand (12.5 $\mu \mathrm{g} / \mathrm{mL})$. (5d) lanthanum Complex good Antimicrobial activity $(6.25 \mu \mathrm{g} / \mathrm{mL})$ and to (3d) Ligand $(12.5 \mu \mathrm{g} / \mathrm{mL})$ up to MIC value compared to (4d) zinc complex $(25 \mu \mathrm{g} / \mathrm{mL})$. (4e) zinc complex good Antimicrobial activity $(6.25 \mu \mathrm{g} / \mathrm{mL})$ up to MIC value compared to (5e) lanthanum Complex (12.5 $\mu \mathrm{g} / \mathrm{mL})$ and (3e) Ligand (25 $\mu \mathrm{g} / \mathrm{mL})$.

E coli, (5a) lanthanum Complex and (4a) zinc complex moderate Antimicrobial activity (12.5 $\mu \mathrm{g} / \mathrm{mL}$ ) up to MIC value compared to (3a) Ligand (25 $\mu \mathrm{g} / \mathrm{mL})$. (5b) lanthanum complex good antimicrobial activity $(6.25 \mu \mathrm{g} / \mathrm{mL})$ up to MIC value compared to (3b) Ligand $(12.5 \mu \mathrm{g} / \mathrm{mL})$ and (4b) zinc complex (12.5 $\mu \mathrm{g} / \mathrm{mL})$. (5c) lanthanum Complex good Antimicrobial activity $(6.25 \mu \mathrm{g} / \mathrm{mL})$ up to MIC value compared to (4c) zinc complex $(12.5 \mu \mathrm{g} / \mathrm{mL})$ and (3c) Ligand (12.5 $\mu \mathrm{g} / \mathrm{mL})$. (5d) lanthanum complex good Antimicrobial activity $(6.25 \mu \mathrm{g} / \mathrm{mL})$ up to MIC value compared to (3d) Ligand (12.5 $\mu \mathrm{g} / \mathrm{mL})$ and (4d) zinc complex $(25 \mu \mathrm{g} / \mathrm{mL})$. (5e) lanthanum complex 
good antimicrobial activity $(6.25 \mu \mathrm{g} / \mathrm{mL})$ up to MIC value compared to (4e) zinc complex $(12.5 \mu \mathrm{g} / \mathrm{mL})$ and (3e) Ligand $(25 \mu \mathrm{g} / \mathrm{mL})$.

Staphylococcus aureus 1, (5a) lanthanum Complex good Antimicrobial activity $(6.25 \mu \mathrm{g} / \mathrm{mL})$ up to MIC value compared to (3a) Ligand $(12.5 \mu \mathrm{g} /$ $\mathrm{mL}$ ) as well as (4a) zinc complex $(25 \mu \mathrm{g} / \mathrm{mL})$. (5b) lanthanum Complex good Antimicrobial activity (6.25 $\mu \mathrm{g} / \mathrm{mL}$ ) up to MIC value compared to (3b) Ligand $(12.5 \mu \mathrm{g} / \mathrm{mL})$ as well as $(\mathbf{4 b})$ zinc complex $(12.5 \mu \mathrm{g} /$ $\mathrm{mL}$ ). (5c) lanthanum Complex good Antimicrobial activity $(6.25 \mu \mathrm{g} / \mathrm{mL})$ up to MIC value compared to $(3 \mathrm{c})$ Ligand $(12.5 \mu \mathrm{g} / \mathrm{mL})$ as well as $(4 \mathrm{c})$ zinc complex $(6.25 \mu \mathrm{g} / \mathrm{mL})$. (5d) lanthanum Complex good Antimicrobial activity $(6.25 \mu \mathrm{g} / \mathrm{mL})$ and to (3d) Ligand $(6.25 \mu \mathrm{g} / \mathrm{mL})$ up to MIC value compared to (4d) zinc complex (25 $\mu \mathrm{g} / \mathrm{mL})$. (5e) lanthanum Complex good Antimicrobial activity $(6.25 \mu \mathrm{g} / \mathrm{mL})$ up to MIC value compared to (4e) zinc complex (12.5 $\mu \mathrm{g} / \mathrm{mL}$ ) as well as (3e) Ligand $(25 \mu \mathrm{g} / \mathrm{mL})$.

Klebsiella, (5a) lanthanum Complex and (4a) zinc complex moderate antimicrobial activity $(12.5 \mu \mathrm{g} / \mathrm{mL})$ up to MIC value compared to (3a) Ligand $(25 \mu \mathrm{g} / \mathrm{mL})$. (5b) lanthanum Complex good Antimicrobial activity $(6.25 \mu \mathrm{g} / \mathrm{mL})$ up to MIC value compared to (3b) Ligand (12.5 $\mu \mathrm{g} / \mathrm{mL}$ ) and (4b) zinc complex $(12.5 \mu \mathrm{g} / \mathrm{mL})$. (5c) lanthanum Complex good antimicrobial activity $(6.25 \mu \mathrm{g} / \mathrm{mL})$ up to MIC value compared to (4c) zinc complex $(12.5 \mu \mathrm{g} /$ $\mathrm{mL}$ ) and (3c) Ligand (12.5 $\mu \mathrm{g} / \mathrm{mL})$. (5d) lanthanum complex good Antimicrobial activity $(6.25 \mu \mathrm{g} / \mathrm{mL})$ up to MIC value compared to (3d) Ligand $(12.5 \mu \mathrm{g} / \mathrm{mL}$ ) and (4d) zinc complex $(25 \mu \mathrm{g} / \mathrm{mL})$. (5e) lanthanum complex good Antimicrobial activity $(6.25 \mu \mathrm{g} / \mathrm{mL})$ up to MIC value compared to (4e) zinc complex (12.5 $\mu \mathrm{g} / \mathrm{mL}$ ) and (3e) Ligand $(25 \mu \mathrm{g} / \mathrm{mL})$.

Bacillus subtilis (5a) lanthanum Complex good Antimicrobial activity $(6.25 \mu \mathrm{g} / \mathrm{mL})$ up to MIC value compared to (3a) Ligand (12.5 $\mu \mathrm{g} / \mathrm{mL}$ ) and (4a) zinc complex $(25 \mu \mathrm{g} / \mathrm{mL})$. (5b) lanthanum Complex and (3b) Ligand moderate Antimicrobial activity $(12.5 \mu \mathrm{g} / \mathrm{mL}$ ) up to MIC value compared to (4b) zinc complex $(25 \mu \mathrm{g} / \mathrm{mL})$. (5c) lanthanum Complex and (4c) zinc complex good Antimicrobial activity $(6.25 \mu \mathrm{g} /$ $\mathrm{mL}$ ) up to MIC value compared to (3c) Ligand (12.5 $\mu \mathrm{g} / \mathrm{mL}$ ). (5d) lanthanum Complex and (3d) Ligand good Antimicrobial activity $(6.25 \mu \mathrm{g} / \mathrm{mL})$ up to MIC value compared to (4d) zinc complex $(25 \mu \mathrm{g} / \mathrm{mL})$. (5e) lanthanum Complex good Antimicrobial activity $(6.25 \mu \mathrm{g} / \mathrm{mL})$ up to MIC value compared to (4e) zinc complex $(12.5 \mu \mathrm{g} / \mathrm{mL})$ and (3e) Ligand $(25 \mu \mathrm{g} / \mathrm{mL})$.

Staphylococcus aureus 2, (5a) lanthanum Complex good Antimicrobial activity $(6.25 \mu \mathrm{g} / \mathrm{mL})$ up to MIC value compared to (3a) Ligand $(12.5 \mu \mathrm{g} / \mathrm{mL}$ ) and (4a) zinc complex $(25 \mu \mathrm{g} / \mathrm{mL})$. (5b) lanthanum Complex and (3b) Ligand moderate Antimicrobial activity $(12.5 \mu \mathrm{g} / \mathrm{mL})$ up to MIC value compared to (4b) zinc complex $(25 \mu \mathrm{g} / \mathrm{mL})$. (5c) lanthanum Complex good Antimicrobial activity $(6.25 \mu \mathrm{g} / \mathrm{mL})$ up to MIC value compared to (3c) Ligand $(12.5 \mu \mathrm{g} / \mathrm{mL})$ and (4c) zinc complex $(25 \mu \mathrm{g} / \mathrm{mL})$. (5d) lanthanum Complex good Antimicrobial activity $(6.25 \mu \mathrm{g} / \mathrm{mL})$ up to MIC value compared to (3d) Ligand $(12.5 \mu \mathrm{g} / \mathrm{mL})$ and (4d) zinc complex $(25 \mu \mathrm{g} / \mathrm{mL})$. (5e) lanthanum Complex good Antimicrobial activity $(6.25 \mu \mathrm{g} / \mathrm{mL})$ up to MIC value compared to $(4 \mathrm{e})$ zinc complex (12.5 $\mu \mathrm{g} / \mathrm{mL}$ ) and (3e) Ligand $(25 \mu \mathrm{g} / \mathrm{mL})$.

\section{RESULTS AND DISCUSSION}

Schiff bases are amorphous powder and metal complexes having crystalline powder. All the metal complexes are insoluble in water but soluble in DMSO. Metal complexes are stable at room temperature. On heating, they decompose at higher temperature. Analytical data of ligand and metal complexes are summarized below.

1.1 In Ultraviolet-visible spectroscopy observed that Schiff bases and metal complex shows different wavelength of maximum absorption.

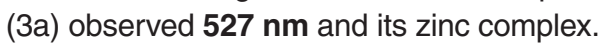

1.2 (4a) observed $\mathbf{3 8 4} \mathbf{~ n m}$ and also lanthanum complex (5a) observed $\mathbf{3 6 3} \mathbf{n m}$. Similarly (3b) observed $\mathbf{5 2 4} \mathbf{~} \mathbf{m}$ and its zinc complex (4b) observed $\mathbf{3 8 4} \mathbf{~ n m}$ also lanthanum complex (5b) observed $\mathbf{3 6 3} \mathbf{n m}$. (3c) observed $\mathbf{5 3 1}$ $\mathrm{nm}$ and its zinc complex (4c) observed $386 \mathrm{~nm}$ and also lanthanum complex (5c) observed $392 \mathbf{~ n m}$. (3d) observed $\mathbf{5 2 3} \mathbf{~ n m}$ and its zinc complex (4d) observed $\mathbf{3 8 8} \mathbf{n m}$ also lanthanum complex (5d) observed $\mathbf{3 8 3} \mathbf{n m}$. (3e) observed $\mathbf{5 2 7} \mathbf{~} \mathbf{m}$ and its zinc complex (4e) observed $384 \mathbf{~ n m}$ and also lanthanum complex (5e) observed $363 \mathbf{~ n m}$.

1.3 In Infrared spectroscopy IR spectra gives the valuable information about the functional group. Comparable studies of IR spectra of 
free ligand were compared with IR spectra of the complex. In IR spectra observed that slightly shifted hydroxyl value but in ester functional group and alkenes value are not changed in Schiff bases and its metal complexes. Hydroxyl value of Schiff bases and its metal complexes are as follows, in $3 a$ to $4 \mathrm{a}$ and $5 \mathrm{a}$ are observed that $2977 \mathrm{~cm}^{-1}$ to $2974 \mathrm{~cm}^{-1}$ and $2981 \mathrm{~cm}^{-1}$ respectively.

1.4 Similarly $3 b$ to $4 b$ and $5 b$ are observed that $2974 \mathrm{~cm}^{-1}, 2920 \mathrm{~cm}^{-1}$ to $2979 \mathrm{~cm}^{-1}, 2932 \mathrm{~cm}^{-1}$ and $2974 \mathrm{~cm}^{-1}$ respectively. In $3 \mathrm{c}$ to $4 \mathrm{c}$ and $5 \mathrm{c}$ are observed that $2962 \mathrm{~cm}^{-1}, 2923 \mathrm{~cm}^{-1}$ to $2973 \mathrm{~cm}^{-1}$ and $2971 \mathrm{~cm}^{-1}$ respectively. In $3 \mathrm{~d}$ to $4 d$ and $5 d$ are observed that $2971 \mathrm{~cm}^{-1}, 2924$ $\mathrm{cm}^{-1}$ to $2986 \mathrm{~cm}^{-1}$ and $2981 \mathrm{~cm}^{-1}, 3353 \mathrm{~cm}^{-1}$ respectively. In $3 e$ to $4 \mathrm{e}$ and $5 \mathrm{e}$ are observed that $2974 \mathrm{~cm}^{-1}, 2921 \mathrm{~cm}^{-1}$ to $3338 \mathrm{~cm}^{-1}, 2975$ $\mathrm{cm}^{-1}, 2944 \mathrm{~cm}^{-1}$ and $3353 \mathrm{~cm}^{-1}, 2974 \mathrm{~cm}^{-1}$, respectively.

$1.5{ }^{1} \mathbf{H}$ NMR Spectra of the ligand taken in DMSO- $\mathrm{d}_{6}$ solvent, azomethine proton in 3 a to 3e observed in range between 9.25 to 9.36 ppm singlets, phenolic $-\mathrm{OH}$ singlet in range between 12.46 to $12.57 \mathrm{ppm}$ and ethoxy group observed in range between 4.34 to $4.35 \mathrm{ppm}(2 \mathrm{H})$ quartet and 2.75 to $2.76(3 \mathrm{H})$ triplet. Aromatic proton in range between 7.06 to $8.35 \mathrm{ppm}$.

1.6 Mass Spectroscopy Formation of Schiff bases is confirmed by presence of intense molecular ion peak.

\section{CONCLUSION}

All are novel Schiff bases have been synthesized and characterized by using different 2-amino benzothiazole derivatives and salicylic aldehyde derivative [Ethyl-2-(3formyl-4-hydroxyphenyl)-4-methyl-1, 3-thiazole- 5-carboxylate]. Novel transition metal complexes have been synthesized and characterized by spectroscopic techniques from above novel Schiff bases and zinc and lanthanum metal.

The spectral data shows that the stoichiometric ratio of the metal and ligand is 1:2. In zinc metal complexes, the ligand is bidentate which is coordinates through azomethine nitrogen of Schiff base and oxygen from salicylic fragment to the zinc metal. Similarly in lanthanum complexes, the ligand is tridentate which is coordinates through azomethine nitrogen of Schiff base, oxygen from salicylic aldehyde fragment and nitrogen from benzothiazole ring.

In vitro data shows the all lanthanum complexes shows the therapeutic benefit, particularly treatment for antifungal agents C. albicans, E.coli, Klebsiella, Staph 1 staph 2.

\section{ACKNOWLEDGEMENT}

We would like to thanks Post graduate and research centre, department of chemistry, Ismail Yusuf college Jogeshwari (E) 400060 India campus for providing the facilities to carry out the research work. We also express thanks the Management of Chikitsak Samuha's Patkar-Varde College of Arts, Science and Commerce, Goregaon (W), Mumbai 400 062, India for consistent support and encouragement. We also appreciate the support provided by Veer Wajekar A. S. C. College, Phunde, and Tal. Uran, Dist. Raigad, and SIES College of Arts, Science and Commerce, Sion (W), Mumbai 400022.

\section{Conflict of Interests}

All authors are declaring that there is no conflict of interest regarding this publication.

\section{REFERENCES}

1. B. H. M. Mruthyunjayaswami, B. K. Shanthaveerapa, Indian J. Chem 39B., 2000, 433-439.

2. D. J. Hadjipavlou-Litina, A. A. Geronikari, Drug design and discovery., 1998, 15(3), 199.

3. F. Gualtiere, G. Brody, A. H. Fieldsteel, W. A.
Skinner, J. Med. Chem., 1971, 14(6), 546.

4. I. Argyropoulou, A. Geronikaki, V. Paola, F. Zani, Arkivok VI., 2009, 89-102.

5. A. Catalano, A. Carocci, I Defrenza, M. Muraglia, A. carrier, F. Van Bambeke, A. Rosato, F. Carbo, C. Franchini, Eur. J. Med. Chem., 2013, 64, 357. 
6. Z. Cimerman, S. Miljanic and N. Galic, Croatica Chemica Acta., 2000, 73(1), 81- 95.

7. P. Singh, R. L. Goel and B. P. Singh, J. Indian Chem. Soc., 1975, 52, 958.

8. K.Y. Lau, A. Mayr, K.K. Cheung, Inorg. Chem. Acta., 1999, 285, 223.

9. A.S, Shawali, N.M.S. Harb, K.O. Badahdah, J. Heterocycl Chem., 1985, 22, 1397.

10. C.T. Supuran, M. Barboiu, C. Luca, E. Pop, M. E. Brewster, A. Dinculescu, Eur. J. Med. Chem., 1996, 31, 597.

11. G. Matela, Anti-Cancer Agents in Medicinal Chemistry (Formerly Current Medicinal Chemistry-Anti-Cancer Agents., 2020, 20(16), 1908-1917.

12. M. N. Bhoi, M. A. Borad, N. K. Panchal, \& H. D. Patel,: Int. Lett. Chem. Phys. Astron., 2015, 53, 106-113.

13. M. N. Noolvi, H. M. Patel, and M Kaur,
European journal of medicinal chemistry., 2012, 54, 447-462.14.

14. D. T. Ruijie, T. John, B. G. Harry, J Med. Chem., 2016, 59, 13.

15. Yoshikawa, T., Naito, Y., Tanigawa, T., Yoneta, T., and Kondo, M. Biochim. Biophys. Acta., 1991, 1115, 15-22.

16. Cho, C. H. Drug Developm. Res., 1992, 27, 61-65.

17. Furuta, S., Toyama, S., Miwa, M., Itabashi, T., Sano, H., and Yoneta, T. Jpn. J. Pharmacol., 1995, 67, 271-278.

18. U. C. Patil, M. C. Mandewale, B. R. Thorat and R. S. Yamgar, Journal of Chemical and Pharmaceutical Research., 2015, 7(8), 159-167.

19. R. Schwalbe, L. Steele-Moore and A. C. Goodwin, eds., Antimicrobial susceptibility testing protocols. Crc Press., 2007. 